a wing of a gigantic dragonfly. The reverse has a small part of the base, not to be seen in the obverse, with a straight sector crossing the horizontal ones. The same arrangement is to be seen in Isophlebia. Every other character important for nearer determination is wanting in the fragment.

Lithentomum Harttii.-The fragment is very insufficient, and recalls the venation of the Sialids, and among them those of the Chauliodes type.

Homothetus fossilis. - This is a Sialid of the Corydalis type, with a small number of transversals. The basal vein, spoken of as homoloyous with the arculus of the Odonata, and as proving a synthetic type, is the part in which the wing breaks off easily in actually living species. I have not seen the type.

Xenoneura antiquorum.-Some details given for this species are not exact. It has not been observed that parts of one wing cover the other; I can only say that the wing belongs to the Neuroptera, and that the venation is nearer to the Chauliodes type than to any other. The famous "stridulation" apparatus at the base is justly retracted by the author.

Four new families are proposed for these insects by the author. One of them, the Atoxina, is now out of the question, as Gerephemera belongs to the Odonata. The three others are only indicated by extremely vague characters, in fact by no characters at all. Can science accept such families? I believe not.

I omit Dyscritus vetushus because this fragment is undeterminable.

My conclusions are, that two of the insects belong to the Odonata, three to the Sialids. There is no Ephemerid among them, nor any synthetic species. The proofs for my statement will be given in a detailed paper.

H. A. HAGEN

Cambridge, Mass.

\section{Ice-Casts of Tracks}

As I was riding along the highway late this afternoon, my attention was attracted to a plenomenon no less curious than beautiful. A couple of days ago there was a fall of a few inches of very damp snow, after which the temperature fell rapidly and this morning everything was frozen hard. A large dog had trotted along in the snow while it was yet damp, and where it lay upon the old drifts by the road-side. To-day the sun has been shining very warm, cutting away all the new snow and leaving the trasks of the dog in exquisitely perfect ice-casts, thin as writing-paper, and standing on the most delicate thread-like columns, about an inch above the surface of the old snow.

Lyons, N.Y., March 7

J. T. BROWNELL

\section{Migration of Birds}

THE following extracts from a work entitled "Bible Customs in Bible Lands," by Henry J. Van Lennep, D.D. (I875), may prove interesting to some of your readers, as containing important and reliable evidence with regard to the migration of birds, which has formed the subject of two recent letters in NATURE.

Speaking of the great numbers of small birds which inhabit Western Asia, as compared with Europe and North America, Dr. Van Lennep explains the circumstance by the fact that "even those of feeblest wing have an easy road from Palestine, Syria, and Mesopotamia, by the Isthmus of Suez, and over the narrow Red Sea, to their winter quarters in tropical Africa, while nature has provided them with extraordinary means of conveyance from A sia Minor southward across the Mediterranean ... The swallow, and many other birds of similar powers of flight, are able to cross over the entire breadth of the Mediterranean, especially by taking advantage of a favourable wind. But many birds are quite incapable of flying over a surface of 350 miles from headland to headland acros; the Mediterranean without alighting, and would require many days, and even weeks, to perform the trip through Syria and Palestine. Such are the ortolans, darnagas, bec-figs, wren, titmouse, smaller thrushes and finehes, with a hundred other diminutive specimens of the feathered tribes.... and as the severity of the winter would be fatal to them, not only in Asia Minor but even in Syria and Palestine, $\mathrm{He}$ who is ever mindful of the smallest of His creatures has provided them with means of transportation to a more genial clime. Many of them, indeed, find their way downward from Palestine into Arabia and Egypt, but this would be difficult, if not impo sible where lofty mountains and broad seas intervene, and to meet such cases the crane has been provided. . . . Most of these birds are migratory. In the autumn numerous flocks may be seen coming from the north with the first cold blasts from that quarter, flying low, and uttering a peculiar cry as if of alarm, as they circle over the cultivated plains. Little birds of every species may then be seen flying up to them, while the twittering songs of those already comfortably settled upon their backs may be distinctly heard. On their return in the spring they fly high, apparently considering that their little passengers can easily find their way down to the earth,'

As Dr. Van Lennep has "spent almost a lifetime in the East," I conclude he has been an eye-witness of the above facts, and therefore his testimony is conclusive.

Bath, March 16

\section{Sound of the Aurora}

WITH reference to the question mooted in last week's NATURE (p. 459) by M. L. Rouse as to the sounds emitted by auroræ, perhaps the accompanying extracts may be of interest.

Brighton, March 20 EDWd. Alloway Paukhurst

$$
\text { "Record of a Girlhood," F. A. Kemble. Vol. I. }
$$

"Standing on that balcony [at Edinburgh] late one cold clear night, I saw for the first time the sky illuminated with the aurora borealis. It was a magnificent display of the phenomenon, and I feel certain that my attention was first attracted to it by the crackling sound which appeared to accompany the motion of the pale flames as they streamed across the sky; indeed crackling is not the word that-properly describes the sound I heard, which was precisely that made by the fickerino of blazing fire; and as I have often since read and heard discussions upon the question whether the motion of the aurora is or is not accompanied by an audible sound, I can only say that on this occasion it was the sound that first induced me to observe the sheets of white light that were leaping up the sky. At this time I knew nothing of such phenomena or the debates among scientific men to which they had given rise, and can therefore trust the impression made on my senses."

I BEG to assure Mr. Rouse that about fifteen years ago, early in the evening, in this very quiet locality, I listened, along with my father, to the sound of an aurora, pulsing above us, across the zenith, and appearing nearer to us, or lower, than most auroras I had seen. The sound was somewhat like the rustling or switching of silk, and we listened to it for some time with great curiosity. The aurora was not coloured, as more imposing ones have sometimes appeared, but white. It recalled to me the lines of Burns in a fragment entitled "A Vision." "The cauld blue north was streaming forth Her lights, wi' hissing eerie din ; Athort the lift they start and shift, Like fortune's favours tint as won."

Dumfriesshire, March 20

J. SHAW

\section{Tacitus on the Aurora}

WITH reference to the passage of Tacitus, "Germ." 45 , quoted in NATURE, vol. xxiii. p. 459, I would suggest that the reading equorum, proposed by some commentators, is far happier than deorum." "It is believed that a sound is heard, that the forms of the horses and rays from a head are seen." K. O. S. Heidelberg, Germany

\section{Aberration of Instinct}

As an instance of "Aberration of Instinct," or I should rather say of instinct at fault, may be mentioned the following :-It is well known, I believe, that rooks in attacking young mangoldwurtzel pick out the plants to obtain the wireworm at their roots. It happens that plants most infested with these insects are the most flagged in the leaf. Now a neighbour whose sowing had been a partial failure transplanted some young wurtzels into the vacant places. These of course for a few days presented a flagged appearance, and were all seized on by the rooks to the exclusion of the rest. Poor disappointed creatures, what must have been their chagrin at finding no wireworm as they evidently expected!

Waldringfield Rectory, Woodbridge, March i6 T. H. WALLER

\section{Squirrels Crossing Water}

A CORRESPONDENT in NATURE (vol, xxiii. p. 340) is surprised to learn of the squirrel taking to the water. It is not an un- 